\title{
Effects of Acute Ischemia in the Dog on Myocardial Blood Flow, Beta Receptors, and Adenylate Cyclase Activity with and without Chronic Beta Blockade
}

\author{
Joel S. Karliner, Michael B. Stevens, Norman Honbo, and Julien I. E. Hoffman \\ Cardiology Section, Veterans Administration Medical Center, San Francisco, California 94121; and the Cardiovascular Research \\ Institute and the Departments of Medicine, Pediatrics and Physiology, University of California, \\ San Francisco, San Francisco, California 94121
}

\begin{abstract}
We ligated the left anterior descending coronary artery for 1 or $\mathbf{2} \mathrm{h}$ in $\mathbf{3 1}$ purebred beagles. We did not detect any changes in $\beta$-adrenergic receptor density or affinity when normal and ischemic zones were compared, either in the subendocardium or in the subepicardium. In the ischemic zones, there was a significant decline in all measures of adenylate cyclase activity, including activity mediated by the $\beta$-adrenergic receptor. By contrast, after chronic $\beta$-adrenergic blockade $(1.5 \mathrm{mg} / \mathrm{kg}$ propranolol i.v. twice daily for $7 \mathrm{~d}$ ), there was an increase in adenylate cyclase activity stimulated by $(-)$-isoproterenol relative to adenylate cyclase activity stimulated by guanyl-5'imidodiphosphate (GppNHp) in both normal and ischemic tissue, suggesting that one effect of chronic $\beta$ blockade may be to enchance coupling between the stimulatory guanine nucleotide regulatory protein (Gs) and the $\beta$-adrenergic receptor, despite a reduction in the number or function of Gs units. Chronic $\beta$ blockade also led to up regulation of $\beta$-adrenergic receptor density in subepicardial regions. After 20 min of reperfusion following $\mathbf{2} \mathrm{h}$ of ischemia, adenylate cyclase activity tended to return to control levels, particularly in the subepicardium, where (-)-isoproterenol-stimulated adenylate cyclase activity was not different from normal myocardium. We conclude that chronic $\beta$-adrenergic blockade may have beneficial effects during prolonged episodes of myocardial ischemia by preserving signal transduction mediated by the $\beta$-adrenergic receptor.
\end{abstract}

\section{Introduction}

The results of several large clinical trials have suggested that $\beta$-adrenergic blockade begun in the early stages of acute myocardial infarction may reduce mortality and morbidity (1-3). Other clinical studies have shown no significant beneficial effect from the early use of $\beta$ blockers in acute ischemia $(4,5)$. Large clinical trials also indicate that chronic $\beta$-adrenergic blockade may reduce the incidence of recurrent myocardial infarction and sudden death in patients with previous infarction $(6,7)$. One explanation for the use of $\beta$-adrenergic antagonists in early myocardial ischemia is that these agents prevent increases in adenylate cyclase activity, possibly as a result of blockade of an augmented number of $\beta$-adrenergic receptors in the ischemic area.

Address reprint requests to Dr. Joel S. Karliner, Cardiology Section (111C) Veterans Administration Medical Center, 4150 Clement Street, San Francisco, CA 94121. 1988.

Received for publication 4 March 1988 and in revised form 29 July

The Journal of Clinical Investigation, Inc.

Volume 83, February 1989, 474-481
There is considerable experimental evidence that $\beta$-adrenergic receptors and their physiological responses may be altered during acute experimental myocardial ischemia. Mukherjee et al. (8) and Ohyanagi et al. (9) demonstrated in dogs that $1 \mathrm{~h}$ of proximal left anterior descending (LAD) ${ }^{1}$ coronary artery ligation was associated with an increased density of $\beta$ adrenergic receptors and that after $15 \mathrm{~min}$ of reflow, during which isoproterenol was administered, cAMP content rose (10). After $1 \mathrm{~h}$ of LAD occlusion, Muntz et al., using an autoradiographic technique, noted a selective increase averaging $18 \%$ in $\beta$-adrenergic receptor density over cardiac myocytes, but not over blood vessels in ischemic myocardium (11). Externalization of $\beta$-adrenergic receptors during acute ischemia has been demonstrated by Maisel et al. (12) and this increase is potentially reversible (13). Recently, Thandroyen et al. have shown in a cardiac myocyte cell culture system derived from neonatal rat ventricle that $2 \mathrm{~h}$ of hypoxia is associated with an increase of $\beta$-adrenergic receptor number and a decrease in isoproterenol-stimulated adenylate cyclase activity (14). By contrast, in the isolated nonblood-perfused working rabbit heart, $1 \mathrm{~h}$ of ischemia was associated with a decline in the maximal number of $\beta$-adrenergic binding sites (15). Similar results have been reported in the rabbit after $30 \mathrm{~min}$ of ischemia (16), and in embryonic chick and neonatal rat ventricular myocytes after $2 \mathrm{~h}$ of hypoxia $(17,18)$.

However, none of these studies have examined the effects of chronic $\beta$-adrenergic blockade on myocardial blood flow, $\beta$-adrenergic receptor density and affinity, and adenylate cyclase activity in acute ischemia. Further, no previous studies have attempted to determine whether there are any differences between subepicardium and subendocardium in these measurements. In this study, we sought to determine the effects of acute myocardial ischemia on $\beta$-adrenergic receptors, signal transduction, and myocardial blood flow in the presence and in the absence of chronic $\beta$-adrenergic blockade. We also studied the effects of reperfusion.

\section{Methods}

33 purebred beagles (Marshall Research Animals, Inc., North Rose, NY) weighing an average of $12.0 \mathrm{~kg}$ (range $9.1-14.5 \mathrm{~kg}$ ) were studied. All dogs underwent ligation of the LAD coronary artery and its major branches to produce acute anterior wall myocardial ischemia. Two dogs died during the study. Of the remaining $31 \mathrm{dogs}, 9 \mathrm{had} 1 \mathrm{~h}$ of ischemia; 4 of these were $\beta$ blocked (see below). The remaining 22 dogs had $2 \mathrm{~h}$ of ischemia; of these, 6 were $\beta$ blocked, and in 5 others the ligation was released to permit $20 \mathrm{~min}$ of reperfusion.

At the start of the study, each dog underwent a left thoracotomy under $1 \%$ halothane general anesthesia and the coronary arteries and

1. Abbreviations used in this paper: DHA, dihydroalprenolol; LAD, left anterior descending. 
left atrium were exposed through a small pericardial incision. After control microsphere measurement of myocardial blood flow, the LAD coronary artery was ligated near its origin to produce a large area of acute ischemia. At the time of ligation, $1-2 \mathrm{mg} / \mathrm{kg}$ lidocaine i.v. was given to reduce the incidence of ventricular arrhythmias. Blood flow measurements were repeated at the end of each study. In the dogs that had release of the LAD ligation, coronary blood flow was also measured at the end of $20 \mathrm{~min}$ of reperfusion.

At the end of each study, the area of central cyanosis distal to the coronary artery occlusion was demarcated in vivo and the heart was immediately removed and placed in iced $50 \mathrm{mM}$ Tris buffer, $\mathrm{pH} 7.4$, before sectioning. The left ventricular free wall was then divided into the previously demarcated ischemic zone anteriorly and a normal posterior zone opposite to the area of ischemia. Each of these zones was then divided transmurally into two equal regions as previously described (19). These will be referred to as subendocardium and subepicardium throughout this manuscript. After mincing these fractions with scissors, aliquots were taken from each tissue sample, weighed and randomly assigned for measurement of myocardial blood flow, $\beta$-adrenergic receptor binding studies, and assay of adenylate cyclase activity.

For the receptor and enzyme analyses, the minced tissue samples from both the ischemic and nonischemic subendocardial and subepicardial areas were homogenized in $0.25 \mathrm{M}$ sucrose, $1 \mathrm{mM}$ EDTA and 5

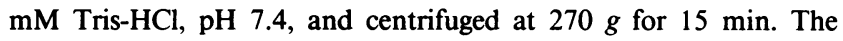
supernatant was then pelleted at $41,300 \mathrm{~g}$ for $15 \mathrm{~min}$ and the pellet was washed two additional times in the same buffer and frozen in liquid nitrogen. The samples were stored at $-70^{\circ} \mathrm{C}$ until analysis several weeks later. Previous studies showed that there is no loss of either receptor binding or adenylate cyclase activity under these circumstances compared with fresh tissue (19).

Myocardial blood flow. For each measurement of myocardial blood flow, radioactive microspheres (average mean diameter $15 \pm 2 \mu \mathrm{m}$ [SD]) were labeled with ${ }^{153} \mathrm{Gd},{ }^{57} \mathrm{Co},{ }^{51} \mathrm{Cr},{ }^{113} \mathrm{Sn},{ }^{85} \mathrm{Sr},{ }^{95} \mathrm{Nb},{ }^{114} \mathrm{In}$, or ${ }^{65} \mathrm{Zn}$. Using the reference sample technique (20), 1-2 million microspheres were injected into the left atrium after thorough agitation. Reference sample collection from a distal aortic catheter began $5 \mathrm{~s}$ before injection and continued for $2 \mathrm{~min}$, using a Holter pump at a constant withdrawal rate of $15 \mathrm{ml} / \mathrm{min}$. Injection of microspheres had no effect on heart rate or mean aortic pressure in any dog. A leastsquares radionuclide separation technique was used to determine regional myocardial blood flow (21).

Radioligand binding studies. For $\beta$-adrenergic receptor analyses, $\left[{ }^{3} \mathrm{H}\right]$ dihydroalprenolol (DHA) was used as previously described (22). At the time of assay, membrane pellets were resuspended in a buffer containing $50 \mathrm{mM}$ Tris- $\mathrm{HCl}, \mathrm{pH} 7.4 ; 10 \mathrm{mM} \mathrm{MgCl}$; and varying amounts of $\left[{ }^{3} \mathrm{H}\right] \mathrm{DHA}$ ranging from 1.4 to $35 \mathrm{nM}$. Binding experiments were conducted for $30 \mathrm{~min}$ in a final sample volume of $100 \mu \mathrm{l}$ at $25^{\circ} \mathrm{C}$. The binding reaction was terminated by adding $4 \mathrm{ml}$ of $50 \mathrm{mM}$ Tris$\mathrm{HCl}$ at $25^{\circ} \mathrm{C}$, followed by immediate rapid vacuum filtration through glass fiber filters (GF/C, Whatman, Inc., Clifton, $\mathrm{NJ}$ ) using a cell harvester (Brandel, Gaithersburg, MD). The test tubes and filters were washed with an additional $15 \mathrm{ml}$ of buffer and the radioactivity retained on the filter was determined in a liquid scintillation counter at $38 \%$ efficiency. Nonspecific binding was defined as that component of total binding not inhibited by $1 \mu \mathrm{M}(-)$-propranolol and did not exceed $20 \%$ of total binding.

All radioligand binding studies were carried out in triplicate. Analysis of saturation binding isotherms was performed according to the method of Scatchard (23). Protein was determined by the method of Lowry et al., using BSA as standard (24).

Adenylate cyclase activity. Adenylate cyclase activity was determined by a modification (Alvarez, R., and K. Littschwager, manuscript submitted for publication) of the method of Ramachandran (25). The assay mixture contained, in a final volume of $200 \mu \mathrm{l}, 0.083$ $\mathrm{mM}\left[\alpha-{ }^{32}\right.$ P]ATP $\left(1-2 \times 10^{5} \mathrm{cpm}\right), 1.7 \mathrm{mM} \mathrm{MgCl}, 0.33 \mathrm{mM}$ cAMP, $0.42 \mathrm{mM}$ Tris-Hepes buffer ( $\mathrm{pH}$ 7.5), $4.2 \mathrm{U}$ creatine kinase, $11 \mathrm{mM}$ phosphocreatine, and 60-120 $\mu \mathrm{g}$ of protein. Incubations were carried out at $30^{\circ} \mathrm{C}$ for $30 \mathrm{~min}$ and the results obtained were linear with time and protein concentration. To terminate the reaction, $580 \mu \mathrm{l}$ of a stopping solution $\left({ }^{3} \mathrm{H}\right.$-cAMP in $\left.0.345 \mathrm{~N} \mathrm{HCl}\right)$ was added to each tube and the tube was heated to $100^{\circ} \mathrm{C}$ in a heating block for $3 \mathrm{~min} .220 \mu \mathrm{l}$ of 1.0 M Tris base was added and the samples were centrifuged at 2,500 rpm in a tabletop centrifuge for $10 \mathrm{~min}$ and then passed over a disposable column containing $1.5 \mathrm{~g}$ fresh, dry neutral alumina adsorption gel (AG7; Bio-Rad Laboratories, Richmond, CA). The column was eluted with $3.0 \mathrm{ml}$ of Tris- $\mathrm{HCl}, \mathrm{pH} 7.5$ and the eluent was collected and counted in scintillation vials containing $12 \mathrm{ml}$ of Beta-Phase (WestChem, San Diego, CA). Recovery of added ${ }^{3} \mathrm{H}$-cAMP was $90-95 \%$. Maximum adenylate cyclase activity was assessed by measuring cAMP production in the presence of $10 \mathrm{mM} \mathrm{NaF}$; membranes were also incubated separately with $0.1 \mathrm{mM}$ guanyl-5'-imidodiphosphate (GppNHp). Because canine myocardial membranes respond poorly to (-)-isoproterenol stimulation alone at $1 \mu \mathrm{M}$, we also measured what we have called net (-)-isoproterenol stimulation (19). This value is calculated by subtracting the GppNHp-stimulated activity from the sum of the latter plus $1 \mu \mathrm{M}(-)$-isoproterenol-stimulated activity. This is similar to the approach previously described by Marsh et al. (26).

$\beta$ blockade. In $10 \mathrm{dogs}, 1.5 \mathrm{mg} / \mathrm{kg}$ propranolol was given twice daily for $1 \mathrm{wk}$ through an indwelling venous catheter implanted in a neck vein under sterile conditions. The adequacy of $\beta$ blockade was confirmed in each dog by the heart rate response to $0.3 \mu \mathrm{g} / \mathrm{kg}$ of isoproterenol given in a rapid intravenous bolus. Before $\beta$ blockade, the peak heart rate response to isoproterenol was an increase of $58.7 \pm 27.5$ (SD) beats per minute (bpm) (range 28 to 122), whereas after $\beta$ blockade it was $6.6 \pm 13.8 \mathrm{bpm}$ (range -12 to $28, P<0.0005$ ). Although isoproterenol has a short half life, to preclude any potential effects of this agent on the results, each dog was tested for its heart rate response the day before the experiment $2-3 \mathrm{~h}$ after dosing with propranolol. The experiment was carried out the next day at approximately the same time, after the morning dose of propranolol, and after the usual evening dose of the $\beta$ blocker given the day before.

Statistical analysis. All data are expressed as mean \pm one SD. For comparisons, $t$ test for paired or unpaired data was used as appropriate. Although our intention was to obtain data on myocardial blood flow, $\beta$ receptors and adenylate cyclase activity from each sample, sufficient tissue was not always available for analysis. Sample numbers are indicated in the tables and figures for each analysis.

\section{Results}

(a) Myocardial blood flow (Table I). All available blood flow data are shown in Table I. In control, normal subendocardium and subepicardium ischemia did not cause any significant alterations in myocardial blood flow. By contrast, after $\beta$ blockade there was a significant decrease in blood flow in both normal subendocardium and subepicardium, possibly due to diminished metabolic demands. In the territory supplied by the LAD coronary artery, $1-2 \mathrm{~h}$ of ischemia resulted in marked declines in both subendocardial and subepicardial blood flow in control dogs by 80 and $73 \%$, respectively, relative to baseline values. The decline of blood flow after ischemia during $\beta$ blockade was similar ( $88 \%$ for subendocardium and $81 \%$ for subepicardium). Chronic $\beta$-adrenergic blockade thus appeared to have no effect on the degree of myocardial ischemia produced by acute coronary artery ligation as measured by alterations in myocardial blood flow.

(b) $\beta$-adrenergic receptors (Table II). In the subendocardium, neither control nor $\beta$-blocked dogs showed any increase in $\beta$-adrenergic receptor density in the ischemic zone after LAD ligation. In the control dogs, receptor affinity for antagonist $\left(K_{\mathrm{d}}\right)$ also was unchanged. In the $\beta$-blocked dogs, there was a significant increase in $K_{d}$ values both in the normal and ischemic tissues compared with the control dogs. 
Table I. Myocardial Blood Flow

\begin{tabular}{|c|c|c|c|c|c|c|c|}
\hline \multicolumn{8}{|c|}{$1-2-\mathrm{h}$ ischemia } \\
\hline \multicolumn{4}{|c|}{ Normal myocardium $(n=20)$} & \multicolumn{4}{|c|}{ Ischemic myocardium $(n=19)$} \\
\hline \multicolumn{2}{|c|}{ Subendocardium } & \multicolumn{2}{|c|}{ Subepicardium } & \multicolumn{2}{|c|}{ Subendocardium } & \multicolumn{2}{|c|}{ Subepicardium } \\
\hline Before & After & Before & After & Before & After & Before & After \\
\hline \multicolumn{8}{|c|}{$m g /$ min per $g$ wet $w t$} \\
\hline \multicolumn{8}{|c|}{ Control } \\
\hline $0.75 \pm 0.20$ & $0.68 \pm 0.24$ & $0.63 \pm 0.17$ & $0.73 \pm 0.31$ & $0.69 \pm 0.19$ & $0.14 \pm 0.15^{*}$ & $0.67 \pm 0.19$ & $0.18 \pm 0.18^{*}$ \\
\hline \multicolumn{8}{|c|}{$\beta$ blocked $(n=10)$} \\
\hline $0.57 \pm 0.15^{\ddagger}$ & $0.82 \pm 0.45^{\S}$ & $0.50 \pm 0.15^{\ddagger}$ & $0.80 \pm 0.55^{\S}$ & $0.57 \pm 0.17$ & $0.07 \pm 0.05^{*}$ & $0.53 \pm 0.20$ & $0.10 \pm 0.07^{*}$ \\
\hline
\end{tabular}

Results before and after LAD ligation were compared using a paired $t$ test; control vs. $\beta$-blocked data were analyzed using an unpaired $t$ test. ${ }^{*} P<0.0005$ vs. before. ${ }^{\ddagger} P<0.025$ vs. non- $\beta$ blocked. ${ }^{\S} P<0.05$ vs. before.

In the subepicardium, there was a significant increase in $\beta$-receptor density in the normal $\beta$-blocked samples compared with the normal tissue in the control dogs, but no difference in the $\beta$-blocked ischemic zones compared with the non- $\beta$ blocked ischemic areas. As in the subendocardium, $K_{\mathrm{d}}$ values in both the normal and ischemic $\beta$-blocked tissues were significantly increased compared with the samples from the control dogs.

(c) Adenylate cyclase activity (Table III). After 1-2 h of subendocardial ischemia, there were significant declines in $\mathrm{NaF}-$, GppNHp-, and net (-)-isoproterenol-stimulated adenylate cyclase activity when normal and ischemic tissues were compared. Similar results were noted in the $\beta$-blocked tissues. In the subepicardium, ischemia also resulted in significant decreases in all measures of adenylate cyclase activity in both control and $\beta$-blocked samples save for $\mathrm{NaF}$-stimulated activity in the $\beta$-blocked subepicardium.
In both the subendocardium and the subepicardium, however, $\beta$ blockade resulted in enhancement of $(-)$-isoproterenol-stimulated adenylate cyclase activity in both ischemic and nonischemic tissue compared with their respective control values. Further, the ratio of net (-)-isoproterenol-stimulated adenylate cyclase activity to GppNHp-stimulated enzyme activity was increased by chronic $\beta$-adrenergic blockade, both in normal and in ischemic tissue, suggesting that one effect of chronic $\beta$ blockade may be to enhance coupling between the stimulatory guanine nucleotide regulatory protein and the $\beta$ adrenergic receptor (Table IV).

(d) Reperfusion. 20 min of reperfusion produced an increase in subendocardial blood flow of $2.45 \pm 1.8$-fold over control levels. In the subepicardium this increase was $1.73 \pm 1.26$-fold over control levels, indicating substantial reactive hyperemia. By contrast, in the nonischemic areas, the values for subendocardium and subepicardium were only

Table II. Maximum Number of Binding Sites and Receptor Affinity

\begin{tabular}{|c|c|c|c|c|}
\hline & \multicolumn{4}{|c|}{ 1-2-h ischemia } \\
\hline & \multicolumn{4}{|c|}{ Subendocardium } \\
\hline & \multicolumn{2}{|c|}{ Control $(n=13)$} & \multicolumn{2}{|c|}{$\beta$ blocked $(n=8)$} \\
\hline & Nonischemic & Central ischemic zone & Nonischemic & Central ischemic zone \\
\hline$B_{\max }(\mathrm{fmol} / \mathrm{mg}$ protein $)$ & $148 \pm 85$ & $131 \pm 62$ & $142 \pm 73$ & $164 \pm 60$ \\
\hline \multirow[t]{3}{*}{$K_{\mathrm{d}}(n M)$} & $7.97 \pm 6.45$ & $10.33 \pm 11.1$ & $19.0 \pm 10.2^{*}$ & $29.2 \pm 24.3^{\ddagger}$ \\
\hline & \multicolumn{4}{|c|}{ Subepicardium } \\
\hline & \multicolumn{2}{|c|}{$(n=14)$} & \multicolumn{2}{|c|}{$(n=8)$} \\
\hline$B_{\max }(\mathrm{fmol} / \mathrm{mg}$ protein $)$ & $119 \pm 46$ & $108 \pm 43$ & $178 \pm 54^{\S}$ & $126 \pm 62$ \\
\hline$K_{\mathrm{d}}(n M)$ & $5.02 \pm 3.25$ & $5.28 \pm 4.17$ & $19.88 \pm 6.48^{*}$ & $17.14 \pm 5.97^{*}$ \\
\hline
\end{tabular}

All data are mean \pm 1 SD. Results within each group (nonischemic vs. ischemic) were compared using a paired $t$ test. Data between groups (control vs. $\beta$ blocked) were analyzed using an unpaired $t$ test. ${ }^{*} P<0.005$ vs. control. ${ }^{\ddagger} P<0.0125$ vs. control. ${ }^{\S} P<0.01$ vs. control. 


\begin{tabular}{|c|c|c|c|c|}
\hline & \multicolumn{4}{|c|}{ Subendocardium } \\
\hline & \multicolumn{2}{|c|}{ Control $(n=13)$} & \multicolumn{2}{|c|}{$\beta$ blocked $(n=9)$} \\
\hline & Nonischemic & Central ischemic zone & Nonischemic & Central ischemic zone \\
\hline & \multicolumn{4}{|c|}{ pmol/mg per $30 \mathrm{~min}$} \\
\hline Basal & $284 \pm 178$ & $292 \pm 222$ & $328 \pm 154$ & $178 \pm 102^{*}$ \\
\hline $\mathrm{NaF}$ & $1,633 \pm 1,437$ & $891 \pm 462^{\ddagger}$ & $2,553 \pm 1,277$ & $1,310 \pm 452^{8 \|}$ \\
\hline GppNHp & $612 \pm 371$ & $338 \pm 142^{\S}$ & $643 \pm 404$ & $226 \pm 115^{1 * *}$ \\
\hline \multirow[t]{3}{*}{ Net Iso } & $975 \pm 841$ & $332 \pm 302^{\S}$ & $1,574 \pm 674^{* *}$ & $716 \pm 387^{\S \ddagger}$ \\
\hline & \multicolumn{4}{|c|}{ Subepicardium } \\
\hline & \multicolumn{2}{|c|}{$(n=12)$} & \multicolumn{2}{|c|}{$(n=9)$} \\
\hline Basal & $273 \pm 125$ & $261 \pm 137$ & $372 \pm 150$ & $323 \pm 140$ \\
\hline $\mathrm{NaF}$ & $2,592 \pm 1,381$ & $1,752 \pm 891^{\S}$ & $2,664 \pm 1,192$ & $2,044 \pm 630$ \\
\hline GppNHp & $841 \pm 369$ & $573 \pm 296^{\S}$ & $659 \pm 272$ & $433 \pm 163^{85}$ \\
\hline Net Iso & $1,177 \pm 686$ & $795 \pm 463^{8}$ & $1,889 \pm 751^{11}$ & $1,311 \pm 414^{\ddagger \neq \$ 8}$ \\
\hline
\end{tabular}

All data are mean \pm 1 SD. Results within each group (nonischemic vs. ischemic) were compared using a paired $t$ test. Data between groups (control vs. $\beta$ blocked) were analyzed using an unpaired $t$ test. NaF- and GppNHp-stimulated adenylate cyclase activities are minus basal activity. See Methods for definition of "Net Iso" activity. ${ }^{*} P<0.005$ vs. nonischemic. ${ }^{\ddagger} P<0.025$ vs. nonischemic. ${ }^{\S} P<0.005$ vs. nonischemic. " $P<0.025$ vs. control. " $P<0.01$ vs. nonischemic. ${ }^{* *} P<0.05$ vs. control. ${ }^{\sharp} P<0.0125$ vs. control. ${ }^{\$} P<0.05$ vs. nonischemic.

$1.14 \pm 0.35$ and $1.11 \pm 0.27$-fold compared with control, indicating no substantial change in myocardial blood flow.

In the subendocardium there was a modest decrease in the maximum number of $\beta$-adrenergic binding sites after $2 \mathrm{~h}$ of ischemia and $20 \mathrm{~min}$ of reperfusion (Table $\mathrm{V}$ ), with no change in $K_{\mathrm{d}}$. Reperfusion had no significant effect on the decline in adenylate cyclase activity noted after $2 \mathrm{~h}$ of ischemia (Table VI).

Table IV. Adenylate Cyclase Activity: Ratio of Net Isoproterenol to GppNHp-Basal Activity

\begin{tabular}{|c|c|c|c|}
\hline \multicolumn{4}{|c|}{ Subendocardium } \\
\hline \multicolumn{2}{|r|}{ Control } & \multicolumn{2}{|c|}{$\beta$ blocked $(n=7)$} \\
\hline $\begin{array}{l}\text { Nonischemic } \\
\quad(n=13)\end{array}$ & $\begin{array}{l}\text { Central ischemic zone } \\
\qquad(n=11)\end{array}$ & Nonischemic & Central ischemic zone \\
\hline $1.35 \pm 0.41$ & $1.18 \pm 0.73$ & $2.47 \pm 0.75^{*}$ & $4.36 \pm 3.05^{\ddagger \S}$ \\
\hline \multicolumn{4}{|c|}{ Subepicardium } \\
\hline \multicolumn{2}{|r|}{$(n=12)$} & \multicolumn{2}{|r|}{$(n=9)$} \\
\hline i. $.56 \pm 0.73$ & $1.41 \pm 0.76$ & $3.46 \pm 1.99^{\ddagger}$ & $3.43 \pm 1.79^{\ddagger}$ \\
\hline
\end{tabular}

All data are mean \pm 1 SD. Results within each group (nonischemic vs. ischemic) were compared using a paired $t$ test. Data between groups (control vs. $\beta$ blocked) were analyzed using an unpaired $t$ test. For the $\beta$-blocked subendocardium only, the ischemic vs. nonischemic data were compared using the Wilcoxon rank sum test for matched pairs.

$* P<0.005$ vs. control.

$\ddagger P<0.01$ vs. control.
Similarly, in the subepicardium there were no significant changes in $\beta$-adrenergic receptor density or affinity after $2 \mathrm{~h}$ of ischemia and $20 \mathrm{~min}$ of reperfusion (Table V). As shown in Table VI, however, although adenylate cyclase activity stimulated by $\mathrm{NaF}$ and $\mathrm{GppNHp}$ was still reduced, the reduction in $\mathrm{NaF}$-stimulated activity was considerably less than that observed in the subendocardium, whereas net (-)-isoproterenolstimulated activity was unchanged from control values. These observations indicate that reperfusion can produce a return toward control levels of adenylate cyclase activity mediated by the $\beta$-adrenergic receptor.

\section{Discussion}

Effects of acute ischemia. It is well known that severe acute myocardial ischemia leads to marked alterations in myocardial structure and function (27). The generalized reduction in

Table V. 2-h Ischemia, 20-min Reperfusion $(n=5)$

\begin{tabular}{|c|c|c|c|}
\hline & \multicolumn{2}{|c|}{ Subendocardium } & \multirow[b]{2}{*}{$P$} \\
\hline & Nonischemic & $\begin{array}{c}\text { Central ischemic } \\
\text { zone after reperfusion }\end{array}$ & \\
\hline$B_{\max }($ fmol/mg protein $)$ & $122 \pm 34$ & $105 \pm 24.5$ & $<0.05$ \\
\hline \multirow[t]{2}{*}{$K_{\mathrm{d}}(n M)$} & $8.5 \pm 8.3$ & $4.7 \pm 7.7$ & NS \\
\hline & \multicolumn{2}{|c|}{ Subepicardium } & \\
\hline$B_{\max }(f m o l / m g$ protein $)$ & $76 \pm 40$ & $89 \pm 27$ & NS \\
\hline$K_{\mathrm{d}}(n M)$ & $2.63 \pm 0.83$ & $3.45 \pm 2.4$ & NS \\
\hline
\end{tabular}

All data are mean \pm 1 SD and were analyzed using a paired $t$ test. 
Table VI. Adenylate Cyclase Activity: 2-h Ischemia, 20-min Reperfusion

\begin{tabular}{lcccc}
\hline & & \multicolumn{3}{c}{ Subendocardium } \\
\cline { 3 - 5 } & $n$ & Nonischemic & $\begin{array}{c}\text { Central ischemic } \\
\text { zone after reperfusion }\end{array}$ & $P$ \\
\hline Basal & 5 & $117 \pm 44$ & $154 \pm 123$ & NS \\
NaF & 4 & $2,114 \pm 919$ & $1,047 \pm 815$ & $<0.01$ \\
GppNHp & 5 & $659 \pm 668$ & $383 \pm 387$ & NS \\
Net Iso & 5 & $544 \pm 411$ & $114 \pm 122$ & $<0.05$ \\
& \multicolumn{4}{c}{ Subepicardium } \\
Basal & 5 & $148 \pm 76$ & $123 \pm 5$ & \\
NaF & 5 & $1,860 \pm 1,184$ & $1,382 \pm 1,074$ & $<0.025$ \\
GppNHp & 5 & $741 \pm 727$ & $555 \pm 619$ & $<0.05$ \\
Net Iso & 5 & $581 \pm 490$ & $524 \pm 456$ & NS \\
& & & & \\
\hline
\end{tabular}

All data are mean \pm 1 SD and were analyzed using a paired $t$ test.

adenylate cyclase activity that we noted after severe ischemia is consistent with deterioration in myocardial membrane function, because this enzyme is a membrane bound molecular complex. That at least in the subepicardium adenylate cyclase activity tends to return rapidly to control levels after reperfusion suggests that the injury is reversible, despite its association with severe reductions of myocardial blood flow. Our observations regarding adenylate cyclase activity are consistent with those previously noted by others $(14,16-18,28-32)$. Hence, it is apparent that despite prior reports of increased $\beta$-adrenergic receptor density $(8-14,30,31)$, adenylate cyclase activity transduced by the $\beta$ receptor in acute ischemia is diminished. One potential consequence of massive catecholamine release accompanying acute ischemia is that it should actually lead to downregulation of the $\beta$-adrenergic receptor (33). The lack of change in adrenergic receptor density and affinity that we observed thus may actually represent relative upregulation in the face of well-documented increases in the local release of catecholamines in ischemic myocardium (34-36). Indeed, a number of reports have suggested that there is either no change or a decrease in $\beta$-receptor density when normal and ischemic or hypoxic tissues are compared in crude membrane preparations from the dog (32), guinea pig (37), and rabbit $(15,16)$ or in intact embryonic chick or neonatal rat ventricular myocytes $(17,18)$.

The preservation of adrenergic receptor density and loss of isoproterenol-stimulated activity that we observed argue either for defective coupling between the $\beta$-adrenergic receptor and the adenylate cyclase complex, or a decrease or alteration in the number of functionally active stimulatory guanine nucleotide regulatory (Gs) units because both GppNHp- and $\mathrm{NaF}$-stimulated activities were also reduced. In ischemic myocardial tissue, Devos et al. demonstrated that the concentration of isoproterenol required for half-maximal adenylate cyclase activation was identical in control and ischemic tissues and that the ischemic area demonstrated a marked increase in the number of low-affinity sites as measured by isoproterenol competition curves compared with control nonischemic myocardium (29). Similar results were reported by Freissmuth et al. (32).
Effects of $\beta$-adrenergic blockade. Previous studies of the $\beta$-receptor after chronic $\beta$-adrenergic blockade have yielded conflicting results, both increases in receptor density (38-44) or no change having been reported (45-50). By contrast, prior reports regarding adenylate cyclase activity after chronic $\beta$ blockade are more consistent. Cooper et al. thus observed no change in maximal adenylate cyclase activity stimulated by isoproterenol but did demonstrate a shift of the isoproterenol dose-response curve to the left (49). Cramb et al. (39) noted an increase in all measures of adenylate cyclase activity and Manning et al. (51) reported no reduction in adenylate cyclase activity in response to isoproterenol after chronic $\beta$-adrenergic blockade. Baumann et al. reported that $\beta$ blockade prevented loss of isoproterenol-stimulated adenylate cyclase activity in the right ventricle of the guinea pig $3 \mathrm{~d}$ after left ventricular myocardial infarction (52). However, none of these studies examined $\beta$-adrenergic receptor density or affinity in the presence of acute myocardial ischemia in $\beta$-blocked preparations. Moreover, none of these studies examined subendocardial versus subepicardial differences, nor did they take into account myocardial blood flow.

Our data, which are the first to examine the influence of chronic $\beta$ blockade on $\beta$ receptors and adenylate cyclase activity in experimental acute myocardial ischemia, indicate that $\beta$ blockade has no significant effect on myocardial blood flow during acute ischemia, save for an increase in both subendocardial and subepicardial nonischemic areas after 1-2 $h$ of coronary artery ligation. Our data also indicate that although there was a tendency for $\beta$-adrenergic receptor density to increase after chronic $\beta$-adrenergic blockade both in nonischemic and in ischemic tissue, this was significant only for nonischemic subepicardium. However, in all instances there was a highly significant three to fourfold increase in antagonist $K_{\mathrm{d}}$. This observation, which is similar to reports by Aarons and Molinoff (40) and by Whyte et al. (43), suggests that residual propranolol was present in the particulate preparation from ventricular tissue. This may be because propranolol exhibits considerable lipophilicity and likely persists in a given tissue even after the drug has been eliminated from the plasma (40). Further evidence for adequate $\beta$ blockade in our animal preparation was the virtual absence of an increase in heart rate after a challenge dose of $0.3 \mu \mathrm{g} / \mathrm{kg}$ of (-)-isoproterenol.

Consistent with the trend toward an increase in $\beta$-adrenergic receptor density was the augmented (-)-isoproterenolstimulated adenylate cyclase activity in both subendocardial and subepicardial normal and ischemic areas when $\beta$ blocked was compared with non- $\beta$-blocked tissue. A possible explanation for this relative preservation of agonist-stimulated adenylate cyclase activity is suggested by the observations summarized in Table IV. Despite a reduction in GppNHp-stimulated adenylate cyclase activity during ischemia (Table III), the ratio of (-)-isoproterenol-stimulated to GppNHp-stimulated activity was enhanced by $\beta$-adrenergic blockade, both in normal and in ischemic tissue. In agreement with our observations, Devos et al. also observed a reduction in GppNHp-stimulated adenylate cyclase activity and suggested that prolonged ischemia causes a decrease in the number or conformation of functional stimulatory guanine nucleotide regulatory (Gs) units (29). These data suggest that one mechanism of action of $\beta$ blockade, also proposed by Cooper et al. (49), may be to enhance coupling between the $\beta$-adrenergic receptor and the stimulatory guanine nucleotide regulatory protein so that rela- 
tively more adenylate cyclase is activated despite a reduction in the number or function of Gs units. Although we did not examine agonist affinity, Cooper et al. (49), using isoproterenol competition curves, noted no significant differences either in the proportion or in the affinity of receptors in the high-affinity state after chronic propranolol treatment. These investigators also demonstrated a shift of the isoproterenol dose-response curve to the left (49).

Our results do not exclude the possibility that the clinically observed beneficial effects of $\beta$-adrenergic blockade could be mediated by a reduction in the number or function of guanine nucleotide inhibitory ( $\mathrm{Gi}$ or $\mathrm{Go}$ ) units, alterations in the catalytic unit of adenylate cyclase, protection of mitochondria (53), reduction of myocardial energy utilization (54), attenuation of myocardial acidosis during ischemia $(55,56)$, or modulation of $\beta$-receptor-mediated signal transduction very early (seconds-minutes) after acute myocardial ischemia $(57,58)$. Whether the results derived from our experimental model can help to explain the mechanism whereby chronic $\beta$-adrenergic blockade reduces the incidence of recurrent infarction and sudden death in patients with previous infarction $(6,7)$ remains to be determined. It should be emphasized that the results of clinical studies during acute myocardial ischemia vary depending on the time of initiation of $\beta$-blocker therapy $(2,4)$. Because our studies were carried out during chronic $\beta$ blockade, the results may be potentially applicable only to the situation in which acute ischemia occurs during the course of chronic $\beta$-blocker treatment. As indicated earlier, our measurements of adenylate cyclase activity are consistent with those previously reported in mongrel dogs by others $(27,28)$. However, we cannot exclude the possibility that the purebred beagle could have a different response, particularly with regard to alterations in $\beta$-adrenergic receptor density and externalization during ischemia, which has been demonstrated by others (8-14, 30, 31).

Reperfusion. There is considerable evidence that during relatively brief periods of ischemia the myocardial content of creatine phosphate and purine and pyrimidine nucleotide pools declines $(59,60)$. With reperfusion, creatine phosphate levels tend to return rapidly to normal whereas the latter metabolites remain depressed for hours to days before returning to control levels $(61,62)$. Prolonged periods of ischemia (1-2 h) such as those we induced can produce irreversible structural damage in the canine model $(28,63)$. However, reperfusion after $2 \mathrm{~h}$ of occlusion appears to limit the size of myocardial necrosis and is associated with substantial functional recovery of jeopardized myocardium (64). After short-term occlusion (15 $\mathrm{min}$ ) and reperfusion for $3 \mathrm{~h}$, severely depressed myocardium responds to $\beta$-adrenergic stimulation as indicated by enhanced myocardial thickening (65). In the anesthetized open chest dog model, coronary artery reperfusion at 1 or $3 \mathrm{~h}$ produced an immediate (but transient) improvement in regional myocardial function (66).

Our data indicate that reperfusion for $20 \mathrm{~min}$ after $2 \mathrm{~h}$ of acute LAD occlusion is not associated with an increase in $\beta$-adrenergic receptor density or change in affinity, either in the subendocardium or in the subepicardium. However, in the subepicardium the reduction in NaF-stimulated adenylate cyclase activity was less than in the subendocardium after reperfusion compared with control values. The reduction in net (-)-isoproterenol-stimulated adenylate cyclase activity, which persisted in the subendocardium, was abolished in the subepi- cardium. The $\beta$-adrenergic receptor-adenylate cyclase complex thus appears to return to normal much more quickly in the subepicardium after short-term reperfusion after $2 \mathrm{~h}$ of ischemia. This phenomenon may provide at least a partial explanation for the ability of stunned myocardium to respond to positive inotropic stimuli after reperfusion (65).

\section{Acknowledgments}

We thank Wanda Woloszyn and Gabrielle Blaug for technical assistance and Dr. Robert Nissenson for his advice.

This work was supported by Program Project Grant HL-25847 from the National Heart, Lung, and Blood Institute, the Veterans Administration Research Service, and the California Affiliate, American Heart Association.

\section{References}

1. Hjalmarson, A., D. Elmfeldt, J. Herlitz, S. Holmberg, I. Malek, G. Nyberg, L. Ryden, F. Waagstein, A. Vedin, A. Waldenstrom, J. Waldenstrom, H. Wedel, L. Wilhelmsen, and C. Wilhelmsson. 1981. Effect on mortality of metoprolol in acute myocardial infarction. Lancet. ii:823-827.

2. The International Collaborative Study Group. 1984. Reduction of infarct size with the early use of timolol in acute myocardial infarction. N. Engl. J. Med. 310:9-15.

3. ISIS-1 (First International Study of Infarct Survival) Collaborative Group. 1986. Randomised trial of intravenous atenolol among 16027 cases of suspected acute myocardial infarction: ISIS-1. Lancet. ii:58-66.

4. Roberts, R., C. Croft, H. K. Gold, T. D. Hartwell, A. S. Jaffe, J. E. Muller, S. M. Mullin, C. Packer, E. R. Passamani, W. K. Poole, D. S. Raabe, Jr., R. E. Rude, P. H. Stone, A. G. Turi, B. E. Sobel, J. T. Willerson, E. Braunwald, and MILIS Study Group. 1984. Effect of propranolol on myocardial infarct size in a randomized, blinded, multicenter trial. N. Engl. J. Med. 311:218-224.

5. The MIAMI Trial Research Group. 1985. Metoprolol in acute myocardial infarction (MIAMI). A randomised placebo-controlled international trial. Eur. Heart J. 6:199-226.

6. $\beta$-Blocker Heart Attack Study Group. 1981. The $\beta$-blocker heart attack trial. JAMA (J. Am. Med. Assoc.) 246:2073-2074.

7. The Norwegian Multicenter Study Group. 1981. Timolol-induced reduction in mortality and reinfarction in patients surviving acute myocardial infarction. N. Engl. J. Med. 304:801-807.

8. Mukherjee, A., T. M. Wong, L. M. Buja, R. J. Lefkowitz, and J. T. Willerson. 1979. Beta adrenergic and muscarinic cholinergic receptors in canine myocardium. J. Clin. Invest. 64:1423-1428.

9. Ohyanagi, M., Y. Matsumori, and T. Iwasaki. 1988. $\beta$-adrenergic receptors in ischemic and nonischemic canine myocardium: relation to ventricular fibrillation and effects of pretreatment with propranolol and hexamethonium. J. Cardiovasc. Pharmacol. 11:107-114.

10. Mukherjee, A., L. R. Bush, K. E. McCoy, R. J. Duke, H. Hagler, L. M. Buja, and J. T. Willerson. 1982. Relationship between $\beta$-adrenergic receptor numbers and physiological responses in canine myocardial ischemia. Circ. Res. 50:735-741.

11. Muntz, K., E. G. Olson, G. R. Lariviere, S. D'Souza, Mukherjee, A., J. T. Willerson, and L. M. Buja. 1984. Autoradiographic characterization of beta adrenergic receptors in coronary blood vessels and myocytes in normal and ischemic myocardium of the canine heart. $J$. Clin. Invest. 73:349-357.

12. Maisel, A. S., H. J. Motulsky, and P. A. Insel. 1985. Externalization of $\beta$-adrenergic receptors promoted by myocardial ischemia. Science (Wash. DC). 230:183-186.

13. Buja, L. M., K. H. Muntz, T. Rosenbaum, Z. Haghani, D. K. Buja, A. Sen, K. R. Chien, and J. T. Willerson. Characterization of a potentially reversible increase in $\beta$-adrenergic receptors in isolated, 
neonatal rat cardiac myocytes with impaired energy metabolism. Circ. Res. 57:640-645.

14. Thandroyen, F., K. Muntz, T. Rosenbaum, J. T. Willerson, and L. M. Buja. 1986. Influence of hypoxia on beta adrenergic receptor density and adenylate cyclase activity in isolated neonatal ventricular myocytes. Circulation. 74(Suppl. II):324. (Abstr.)

15. Rhee, H. M., and L. Tyler. 1985. Myocardial ischemic injury and $\beta$-adrenergic receptors in perfused working rabbit hearts. $A d v$. Exp. Med. Biol. 191:281-288.

16. Wolff, A., and J. S. Karliner. 1988. $\mathrm{H}_{2}$-histaminergic and $\beta$ adrenergic adenyl cyclase activation is maintained despite receptor changes and Gs dysfunction during acute myocardial ischemia. Clin. Res. 36:328a. (Abstr.)

17. Marsh, J. D., and K. A. Sweeney. 1987. Hypoxia regulates beta adrenergic receptors and adenylate cyclase in cultured heart cells. Clin. Res. 35:302a. (Abstr.)

18. Rocha-Singh, K., and J. S. Karliner. 1988. Effects of hypoxia and glucose deprivation on $\beta$-adrenergic receptors and cAMP generation in cultured neonatal rat myocardial cells. Clin. Res. 36:312a. (Abstr.)

19. Karliner, J. S., M. Stevens, M. Grattan, W. Woloszyn, N. Honbo, and J. I. E. Hoffman. 1986. Beta-adrenergic receptor properties of canine myocardium: effects of chronic myocardial infarction. $J$. Am. Coll. Cardiol. 8:349-356.

20. Heymann, M. A., B. D. Payne, J. I. E. Hoffman, and A. M. Rudolph. 1977. Blood flow measurements with radioactive-labeled particles. Prog. Cardiovasc. Dis. 20:55-80.

21. Baer, R. W., B. D. Payne, E. D. Verrier, G. S. Vlahakes, D. Molodowitch, P. M. Uhlig, and J. I. E. Hoffman. 1984. Increased numbers of myocardial blood flow measurements with radioanuclidelabeled microspheres. Am. J. Physiol. 246:H418-434.

22. Karliner, J. S., H. J. Motulsky, J. Dunlap, J. H. Brown, and P. A. Insel. 1982. Verapamil competitively inhibits $\alpha_{1}$-adrenergic and muscarinic but not $\beta$-adrenergic receptors in rat myocardium. J. Cardovasc. Pharmacol. 4:515-520.

23. Scatchard, G. 1949. The attraction of proteins for small molecules and ions. Ann. NY Acad. Sci. 51:660-672.

24. Lowry, O. H., N. J. Rosenbrough, A. L. Farr, and R. J. Randall. 1951. Protein measurement with the Folin phenol reagent. J. Biol. Chem. 265:265-275.

25. Ramachandran, J. 1971. A new simple method for separation of adenosine 3', 5'-cyclic monophosphate from other nucleotides and its use in the assay of adenyl cyclase. Anal. Biochem. 43:227-239.

26. Marsh, J. D., W. H. Barry, E. J. Neer, R. W. Alexander, and T. W. Smith. 1980. Desensitization of chick embryo ventricle to the physiological and biochemical effects of isoproterenol. Circ. Res. 47:493-501.

27. Jennings, R. B., H. K. Hawkins, J. E. Lowe, M. L. Hill, S. Klotman, and K. A. Reimer. 1978. Relation between high energy phosphate and lethal injury in myocardial ischemia in the dog. Am. J. Pathol. 92:187-214.

28. Drummond, R. W., and L. A. Sordahl. 1981. Temporal changes in adenylate cyclase activity in acutely ischemic dog heart: evidence of functional subunit damage. J. Mol. Cell. Cardiol. 13:323330.

29. Devos, C., P. Robberecht, P. Nokin, M. Waelbroeck, M. Clinet, J. C. Camus, P. Beaufort, P. Schoenfeld, and J. Christophe. 1985. Uncoupling between beta-adrenoceptors and adenylate cyclase in dog ischemic myocardium. Naunyn-Schmiedebergs Arch. Pharmacol. 331:71-75.

30. Vatner, D. E., D. R. Knight, Y. T. Shen, J. X. Thomas Jr., C. J. Homcy, and S. F. Vatner. 1988. One hour of myocardial ischemia in conscious dogs increases $\beta$-adrenergic receptors but decreases adenylate cyclase activity. J. Mol. Cell. Cardiol. 20:75-82.

31. Thandroyen, F. T., K. Muntz, B. Ziman, T. Rosenbaum, J. T. Willerson, and L. M. Buja. 1987. Temporal changes in beta adrenergic receptor-adenylate cyclase activity during acute myocardial ischemia and reperfusion in canine myocardium. Clin. Res. 35:576a. (Abstr.)
32. Freissmuth, M., W. Schutz, M. Weindlmayer-Gottel, M. Zimpfer, and C. K. Spiss. 1987. Effects of ischemia on the canine myocardial $\beta$-adrenoceptor-linked adenylate cyclase system. J. Cardiovasc. Pharmacol. 10:568-574.

33. Karliner, J. S., P. C. Simpson, N. Honbo, and W. Woloszyn. 1986. Mechanisms and time course of beta ${ }_{1}$ adrenoceptor densensitisation in mammalian cardiac myocytes. Cardiovasc. Res. 20:221-228.

34. Schomig, A., A. M. Dart, R. Dietz, E. Mayer, and W. Kubler. 1984. Release of endogenous catecholamines in the ischemic myocardium of the rat. Circ. Res. 55:689-701.

35. Carlsson, L., T. Abrahamsson, and O. Almgren. 1986. Release of noradrenaline in myocardial ischemia: importance of local inactivation by neuronal and extraneuronal mechanisms. J. Cardiovasc. Pharmacol. 8:545-553.

36. Schomig, A., S. Fischer, T. Kurz, G. Richardt, and E. Schomig. 1987. Nonexocytotic release of endogenous noradrenaline in the ischemic and anoxic rat heart: mechanism and metabolic requirements. Circ. Res. 60:194-205.

37. Maisel, A. S., H. J. Motulsky, M. G. Ziegler, and P. A. Insel. 1987. Ischemia- and agonist-induced changes in $\alpha$ - and $\beta$-adrenergic receptor traffic in guinea pig hearts. Am. J. Physiol. 253:H1159H1166.

38. Glaubiger, G., and J. R. Lefkowitz. 1977. Elevated $\beta$-receptor number after chronic propranolol treatment. Biochem. Biophys. Res. Commun. 78:720-725.

39. Cramb, G., N. M. Griffiths, J. F. Aiton, and N. L. Simmons. 1984. Biochemical and physiological adaptation to chronic propranolol treatment in the rat. Biochem. Pharmacol. 33:1969-1976.

40. Aarons, R. D., and P. B. Molinoff. 1982. Changes in the density of beta adrenergic receptors in rat lymphocytes, heart and lung after chronic treatment with propranolol. J. Pharmacol. Exper. Ther. 221:439-443.

41. Heilbrunn, S. M., P. Shah, H. A. Valentine, A. V. Mullin, R. Ginsburg, J. S. Schroeder, M. R. Bristow, and M. B. Fowler. 1986. Increased beta-receptor density and improved hemodynamic response to catecholamine stimulation during chronic metoprolol therapy. $\mathrm{Cir}$ culation. 74(Suppl. II):310. (Abstr.)

42. Aarons, R. D., A. S. Nies, J. Gal, L. R. Hegstrand, and P. B. Molinoff. 1980. Elevation of $\beta$-adrenergic receptor density in human lymphocytes after propranolol administration. J. Clin. Invest. 65:949957.

43. Whyte, K., C. R. Jones, C. A. Howie, N. Deighton, D. J. Sumner, and J. L. Reid. 1987. Haemodynamic, metabolic, and lymphocyte beta $_{2}$-adrenoceptor changes following chronic beta-adrenoceptor antagonism. Eur. J. Clin. Pharmacol. 32:237-243.

44. Hedberg, A., F. Kempf, Jr., M. E. Josephson, and P. B. Molinoff. 1985. Coexistence of beta- 1 and beta-2 adrenergic receptors in the human heart: effects of treatment with receptor antagonists or calcium entry blockers. J. Pharmacol. Exper. Ther. 234:561-568.

45. Baker, S. P., and L. T. Potter. 1980. Effect of propranolol on $\beta$-adrenoceptors in rat hearts. Br. J. Pharmacol. 68:8-10.

46. Kennedy, R. H., and T. E. Donnelly, Jr. 1982. Cardiac responsiveness after acute withdrawal of chronic propranolol treatment in rats. Gen. Pharmacol. 13:231-239.

47. Mugge, A., C. Reupcke, and H. Scholz. 1985. Increased myocardial $\alpha_{1}$-adrenoceptor density in rats chronically treated with propranolol. Eur. J. Pharmacol. 112:249-252.

48. Chess-Williams, R. G., and K. J. Broadley. 1984. Ex vivo examination of $\beta$-adrenoceptor characteristics after propranolol withdrawal. J. Cardiovasc. Pharmacol. 6:701-706.

49. Cooper, G. IV, R. L. Kent, P. McGonigle, and A. M. Watanabe. 1986. Beta adrenergic receptor blockade of feline myocardium. $J$. Clin. Invest. 77:441-455.

50. Golf, S., and V. Hansson. 1986. Effects of beta blocking agents on the density of beta adrenoceptors and adenylate cyclase response in human myocardium: intrinsic sympathomimetic activity favours receptor upregulation. Cardiovasc. Res. 20:637-644.

51. Manning, A. S., D. M. Yellon, D. J. Coltart, and D. J. Hearse. 
1981. Abrupt withdrawal of chronic beta-blockade: adaptive changes in cyclic AMP and contractility. J. Mol. Cell. Cardiol. 13:999-1009.

52. Baumann, G., G. Riess, W. D. Erhardt, S. B. Felix, L. Ludwig, G. Blumel, and H. Bloomer. 1981. Impaired beta-adrenergic stimulation in the uninvolved ventricle post-acute myocardial infarction: reversible defect due to excessive circulating catecholamine-induced decline in number and affinity of beta-receptors. Am. Heart J. 101:569581.

53. Kloner, R. A., M. C. Fishbein, E. Braunwald, and P. R. Maroko. 1978. Effect of propranolol on mitochondrial morphology during acute myocardial ischemia. Am. J. Cardiol. 41:880-886.

54. Goodlett, M., K. Dowling, L. J. Eddy, and J. M. Downey. 1980. Direct metabolic effects of isoproterenol and propranolol in ischemic myocardium of the dog. Am. J. Physiol. 239:H469-H476.

55. Sakai, K., and Y. Abiko. 1984. Attenuation by atenolol of myocardial acidosis during ischemia in dogs: contribution of beta-1 adrenoceptors to myocardial acidosis. J. Pharmacol. Exper. Ther. 232:810-816.

56. Stevens, M. B., J. S. Karliner, and J. I. E. Hoffman. 1987. Attenuation of myocardial acidosis during acute ischemia by chronic beta-blockade. Circulation. 76(Suppl. IV):378. (Abstr.)

57. Wollenberger, A., E. Krause, and G. Heier. 1969. Stimulation of 3', 5'-cyclic AMP formation in dog myocardium following arrest of blood flow. Biochem. Biophys. Res. Commun. 36:664-670.

58. Rabinowitz, B., W. W. Parmley, M. Kligerman, J. Norman, S. Fujimura, S. Chiba, and J. M. Matloff. 1975. Myocardial and plasma levels of adenosine 3':5'-cyclic phosphate. Chest. 68:69-74.

59. Benson, E. S., G. T. Evans, B. E. Hallaway, C. Phibbs, and E. F. Freier. 1961. Myocardial creatine phosphate and nucleotides in anoxic cardiac arrest and recovery. Am. J. Physiol. 201:687-698.
60. Braasch, W., S. Gudbjarnason, P. Puri, K. Ravens, and R. J. Bing. 1968. Early changes in energy metabolism in the myocardium following acute coronary artery occlusion in anesthetized dogs. Circ. Res. 23:429-438.

61. Reimer, K. A., M. L. Hill, and R. B. Jennings. 1981. Prolonged depletion of ATP and of the adenine nucleotide pool due to delayed resynthesis of adenine nucleotides following reversible myocardial ischemic injury in dogs. J. Mol. Cell. Cardiol. 13:229-239.

62. Swain, J. L., R. L. Sabina, P. A. McHale, J. C. Greenfield, Jr., and E. W. Holmes. 1982. Prolonged myocardial nucleotide depletion after brief ischemia in the open-chest dog. Am. J. Physiol. 242:H818H826.

63. Sharma, G. P., K. G. Varley, S. W. Kim, J. Barwinsky, M. Cohen, and N. S. Dhalla. 1975. Alterations in energy metabolism and ultrastructure upon reperfusion of the ischemic myocardium after coronary occlusion. Am. J. Cardiol. 36:234-243.

64. Ellis, S. G., C. I. Henschke, T. Sandor, J. Wynne, E. Braunwald, and R. A. Kloner. 1983. Time course of functional and biochemical recovery of myocardium salvaged by reperfusion. J. Am. Coll. Cardiol. 1:1047-55.

65. Bolli, R., W. Zhu, M. L. Myers, C. J. Hartley, and R. Roberts. 1985. Beta-adrenergic stimulation reverses postischemic myocardial dysfunction without producing subsequent functional deterioration. Am. J. Cardiol. 56:964-968.

66. Buda, A. J., R. J. Zotz, D. P. Pace, and L. C. Krause. 1986. Immediate rebound followed by deterioration of regional left ventricular function with coronary reperfusion. J. Am. Coll. Cardiol. 8:333341 . 